\title{
Pengukuran Parameter Fisika di Lingkungan Kampus Universitas PGRI Palembang
}

\author{
Atina ${ }^{1^{*}}$, Jumingin ${ }^{1}$ \\ ${ }^{1}$ Program Studi Fisika Fisika, FMIPA Universitas PGRI Palembang, \\ Palembang 30251, Indonesia \\ *e-mail: atina.salsabila@gmail.com
}

Received: 03 Juni 2020. Accepted: 02 Juli 2020. Published: Juli 2020

\begin{abstract}
Abstrak
Tujuan penelitian adalah mengukur parameter fisika meliputi tingkat pencahayaan dan suhu di lingkungan Fakultas Sains dan Teknologi Universitas PGRI Palembang. Metode yang digunakan adalah pengukuran secara langsung dengan lokasi pengukuran 5 titik pengukuran yaitu ruang tata usaha, ruang dosen, ruang kelas, perpustakaan dan laboratorium Fisika dan waktu pengukuran pada pagi, siang dan sore hari. Hasil pengukuran di lapangan dibandingkan dengan nilai yang direkomendasikan sesuai Standar Nasional Indonesia. Hasil pengukuran tingkat pencahayaan di lingkungan kampus A Universitas PGRI Palembang yaitu ruang tata usaha 242 - 350 Lux, ruang dosen 350 - 355 Lux, ruang kelas 245 - 270 Lux, perpustakaan 236 - 309 Lux, Laboratorium Fisika 485 - 571 Lux. Tingkat pencahayaan di lingkungan kampus A Universitas PGRI Palembang telah memenuhi standar nasional Indonesia tahun 2011 mengenai intensitas pencahayaan yang direkomendasikan sesuai dengan peruntukan ruangan. Suhu ruangan di lingkungan kampus A Universitas PGRI Palembang telah memenuhi Peraturan Menteri Kesehatan nomor 48 tahun 2016 dengan hasil pengukuran antara $23-24^{\circ} \mathrm{C}$.
\end{abstract}

Kata Kunci: parameter fisika, pencahayaan, suhu, Universitas PGRI Palembang

\section{Measurement of Physical Parameters in the PGRI University of Palembang}

\begin{abstract}
The research objective was to measure physical parameters including the level of lighting and temperature in the Faculty of Science and Technology, PGRI University of Palembang. The method used was direct measurement with the measurement location of 5 measurement points, namely the administration room, lecturer room, class room, library and physics laboratory and measurement time in the morning, afternoon and evening. The measurement results in the field are compared with the recommended values according to the Indonesian National Standard. The results of measuring the level of lighting in the campus environment of PGRI Palembang University are administration room 242 - 350 Lux, lecturer room 350 - 355 Lux, class room 245 - 270 Lux, library 236 - 309 Lux, Physics Laboratory 485 - 571 Lux. The level of lighting in the campus environment of PGRI Palembang University A has met the 2011 Indonesian national standard regarding the recommended lighting intensity according to the designation of the room. The room temperature in the campus environment A PGRI Palembang University has met the Minister of Health Regulation number 48 of 2016 with measurement results between 23 $24^{\circ} \mathrm{C}$.
\end{abstract}

Keywords: physical parameter, lighting, temperature, PGRI University of Palembang

PENDAHULUAN
Dalam upaya pengendalian dan pemantauan lingkungan hidup, pemerintah Republik Indonesia melalui 
kementrian Lingkungan Hidup dan Kehutanan mewajibkan setiap tempat usaha/kegiatan untuk menyusun dan melaporkan dokumen lingkungan tempat usaha/kegiatannya secara berkala. Peraturan ini tertuang dalam Peraturan menteri Lingkungan Hidup dan Kehutanan Republik Indonesia nomor 102/MENLHK/SETJEN/KUM.1/12/2016 tentang Pedoman Penyusunan Dokumen Lingkungan Hidup Bagi Usaha dan/atau Kegiatan yang telah Memiliki Izin Usaha dan/atau Kegiatan tetapi Belum Memiliki Dokumen Lingkungan Hidup. Berdasarkan peraturan diatas, dokumen lingkungan hidup dapat diartikan sebagai dokumen yang memuat pengelolaan dan pemantauan lingkungan hidup yang terdiri atas analisis mengenai dampak lingkungan hidup (amdal), upaya pengelolaan lingkungan hidup dan upaya pemantauan lingkungan hidup termasuk didalamnya studi evaluasi dampak lingkungan dan penyajian informasi lingkungan.

Lingkungan hidup adalah suatu benda, daya dan kondisi yang terdapat dalam suatu tempat atau ruang tempat manusia dan makhluk hidup berada dan dapat mempengaruhi hidupnya (Bleszeinsky, G dkk, 2019). Karena itulah, penyusunan dokumen lingkungan hidup tidak hanya mempertimbangkan kondisi alam tetapi juga harus mempertimbangkan seluruh komponen yang terkait dengannya. Dalam bidang sains, terdapat parameter yang menjadi acuan pengukuran dalam penyusunan dokumen lingkungan hidup. Parameter ini dapat dijadikan acuan dalam menentukan apakah kondisi lingkungan di lokasi pengukuran telah memenuhi standar baku mutu yang ditetapkan pemerintah. Terdapat 5 parameter pengukuran lingkungan yaitu parameter fisika, kimia dan biologi, ergonomi dan psikologi pekerja. Hal ini sejalan dengan Permenaker no 5 tahun 2018 tentang Keselamatan dan Kesehatan Kerja (K3). Parameter fisika pada lingkungan mencakup iklim kerja, kebisingan, getaran, gelombang radio atau gelombang mikro, sinar ultra ungu (ultra violet), medan magnet statis, tekanan udara dan pencahayaan.

Kampus adalah tempat berjalannya kegiatan (pelayanan publik) akademik yang dalam kesehariannya memberikan pelayanan akademik khususnya kepada mahasiswa. Selain itu juga, kampus memiliki peran strategis dalam pengembangan ilmu pengetahuan dan teknologi guna mendukung kemajuan bangsa dan negara. Oleh karenanya, kampus memiliki kewajiban mensukseskan upaya pemerintah dalam hal pengelolaan lingkungan. Penelitian ini bertujuan untuk mengukur parameter fisika di lingkungan kampus yang merupakan salah satu dasar dari penyusunan laporan dokumen lingkungan yaitu tingkat pencahayaan dan suhu ruangan.

Hasil penelitian ini juga diharapkan mampu memberikan gambaran kondisi lingkungan di kampus Universitas PGRI Palembang sehingga dapat dijadikan dasar dalam penyusunan program lingkungan kampus agar tercipta lingkungan yang sehat dan nyaman.

Lingkungan adalah tempat di sekeliling makhluk hidup untuk dapat melangsungkan kehidupannya meliputi ekosistem dan habitat di sekitar seperti air, tanah dan udara. Lingkungan secara umum dipengaruhi oleh faktor fisika, biologi, kimia, psikologi dan ergonomi. Sedangkan fisika lingkungan dapat diukur pada air, udara dan tanah. Pengukuran fisika lingkungan udara meliputi iklim kerja, kebisingan, ventilasi udara, radiasi gelombang mikro, radiasi ultra ungu, radiasi medan listrik statis, suhu, tekanan udara dan pencahayaan.

Universitas PGRI sebagai pengembangan dari Sekolah Tinggi Keguruan dan Ilmu Pendidikan (STKIP) yang mendapat izin dengan Sk Mendiknas No. 97/D/O/2000 tanggal 9 Juni 2000, berdiri 5 fakultas dan 1 
Pascasarjana

(https://univpgri-

palembang.ac.id) yaitu Fakultas

Keguruan dan Illmu Pendidikan (FKIP), Fakultas Sains dan Teknologi, Fakultas Teknik, Fakultas Perikanan dan kelautan, Fakultas Teknik serta Porgram Pascasarjana.

\section{BAHAN DAN METODE}

$2020 \begin{array}{r}\text { Penelitian dilakukan pada April } \\ \text { dengan mengambil lokasi }\end{array}$ pengambilan data di Fakultas Sains dan Teknologi yaitu di 5 titik berbeda (ruang tata usaha, ruang dosen, ruang kelas, perpustakaan dan laboratorium fisika).

Penelitian yang dilakukan adalah penelitian kuantitatif dengan penyajian data menggunakan analisis deskriptif yang akan ditampilkan dalam bentuk tabel hasil pengukuran. Pengukuran dilakukann terhadap pencahayaan dan suhu ruangan. Pengambilan data dilakukan pada pagi, siang dan sore hari dengan menggunakan lux meter untuk pengukuran pencahayaan dan thermometer ruangan digital untuk pengukuran suhu ruangan.
Pengukuran pencahayaan dan suhu ruangan difokuskan dipusat ruangan yang dengan kondisi semua sumber cahaya dinyalakan dan pendingin ruangan juga pada kondisi on.

\begin{tabular}{lcr}
\multicolumn{1}{c}{ Data } & hasil & \multicolumn{2}{c}{ pengukuran } \\
pencahayaan & dan suhu ruangan \\
dikelompokkan & berdasarkan & waktu \\
pengukuran dan & dibandingkan dengan \\
standar nasional Indonesia untuk baku & dian \\
mutu pencahayaan dan suhu yang \\
diperbolehkan & sesuai & dengan \\
peruntukannya. & Untuk kemudian
\end{tabular}
ditentukan telah memenuhi standar atau tidak.

\section{HASIL DAN PEMBAHASAN}

Pengukuran pencahayaan dan suhu ruangan dilakukan pada pagi hari (jam akan masuk kantor), siang hari (jam istirahat) dan sore hari (menjelang pulang). Data hasil pengukuran untuk pencahayaan dan suhu ruangan disajikan pada tabel 1.

Tabel 1. Data Pengukuran Pencahayaan dan Suhu

\begin{tabular}{|c|c|c|c|c|}
\hline No & Tempat & $\begin{array}{l}\text { Waktu } \\
\text { Pengukuran }\end{array}$ & $\begin{array}{l}\text { Pencahayaan } \\
\text { (Lux) }\end{array}$ & Suhu $\left({ }^{\circ} \mathrm{C}\right)$ \\
\hline 1 & Ruang Tata Usaha & $\begin{array}{l}\text { Pagi } \\
\text { Siang } \\
\text { Sore } \\
\end{array}$ & $\begin{array}{l}242 \\
350 \\
294 \\
\end{array}$ & $\begin{array}{l}23 \\
24 \\
23 \\
\end{array}$ \\
\hline 2 & Ruang Kelas & $\begin{array}{l}\text { Pagi } \\
\text { Siang } \\
\text { Sore }\end{array}$ & $\begin{array}{l}245 \\
270 \\
260\end{array}$ & $\begin{array}{l}23 \\
24 \\
24\end{array}$ \\
\hline 3 & Ruang Dosen & $\begin{array}{l}\text { Pagi } \\
\text { Siang } \\
\text { Sore }\end{array}$ & $\begin{array}{l}350 \\
350 \\
355\end{array}$ & $\begin{array}{l}23 \\
24 \\
24\end{array}$ \\
\hline 4 & Perpustakaan & $\begin{array}{l}\text { Pagi } \\
\text { Siang } \\
\text { Sore } \\
\end{array}$ & $\begin{array}{l}237 \\
309 \\
236\end{array}$ & $\begin{array}{l}24 \\
24 \\
24\end{array}$ \\
\hline 5 & Lab Fisika & $\begin{array}{l}\text { Pagi } \\
\text { Siang } \\
\text { Sore }\end{array}$ & $\begin{array}{l}489 \\
571 \\
485\end{array}$ & $\begin{array}{l}23 \\
23 \\
23\end{array}$ \\
\hline
\end{tabular}

Berdasarkan Standar Nasional lingkungan perkantoran dan lembaga Indonesia tahun 2011 mengenai tingkat pendidikan, diketahui bahwa untuk pencahayaan yang direkomendasikan di pencahayaan di ruang kantor 350 Lux, 
ruang kelas 250 Lux, perpustakaan 300 Lux dan laboratorium 500 Lux. Sedangkan Peraturan Menteri Kesehatan nomor 48 tahun 2016 menyebutkan Temperatur ruang perkantoran harus memenuhi aspek kebutuhan kesehatan dan kenyamanan pemakai ruangan. Untuk dapat memenuhi syarat kesehatan dan kenyamanan suhu ruang perkantoran berkisar $23^{\circ} \mathrm{C}$ sampai $26^{\circ} \mathrm{C}$.

Pada penelitian ini ruang kantor yang diukur adalah ruang tata usaha dan ruang dosen. Pencahayaan di ruang tata usaha berdasarkan hasil pengukuran berada dibawah tingkat pencahayaan yang direkomendasikan. Sedangkan ruang dosen memenuhi nilai tingkat pencahayaan yang direkomendasikan. Tabel berikut menjelaskan perbandingan hasil pengukuran pencahayaan dan suhu dengan nilai yang direkomendasikan sesuai Standar Nasional Indonesia.

Tabel 2. Perbandingan Tingkat pencahayaan dengan rekomendasi Standar Nasional Indonesia

\begin{tabular}{|l|l|l|l|}
\hline No & Titik Pengukuran & $\begin{array}{l}\text { Rekomendasi SNI } \\
(\text { Lux })\end{array}$ & $\begin{array}{l}\text { Hasil Pengukuran } \\
(\text { Lux })\end{array}$ \\
\hline 1 & Ruang Tata Usaha & 350 & $242-350$ \\
\hline 2 & Ruang Dosen & 350 & $350-355$ \\
\hline 3 & Ruang Kelas & 250 & $245-270$ \\
\hline 4 & Perpustakaan & 300 & $236-309$ \\
\hline 5 & Laboratorium Fisika & 500 & $485-571$ \\
\hline
\end{tabular}

Tabel 3. Perbandingan hasil pengukuran suhu dengan rekomendasi SNI

\begin{tabular}{|l|l|c|l|}
\hline No & Titik Pengukuran & $\begin{array}{c}\text { Rekomendasi SNI } \\
\left({ }^{\circ} \mathrm{C}\right)\end{array}$ & $\begin{array}{c}\text { Hasil Pengukuran } \\
\left({ }^{\circ} \mathrm{C}\right)\end{array}$ \\
\hline 1 & Ruang Tata Usaha & & $23-24$ \\
\hline 2 & Ruang Dosen & \multirow{2}{*}{$23-26$} & $23-24$ \\
\hline 3 & Ruang Kelas & & $23-24$ \\
\hline 4 & Perpustakaan & & 24 \\
\hline 5 & Laboratorium Fisika & & 23 \\
\hline
\end{tabular}

Berdasarkan Tabel 2 dan Tabel 3 diketahui bahwa tingkat pencahayaan dan suhu di titik pengukuran secara umum memenuhi standar yang direkomendasikan.

\section{KESIMPULAN}

Hasil pengukuran tingkat pencahayaan di lingkungan kampus A Universitas PGRI Palembang yaitu ruang tata usaha 242 - 350 Lux, ruang dosen 350 - 355 Lux, ruang kelas 245 - 270 Lux, perpustakaan 236 - 309 Lux, Laboratorium Fisika 485 - 571 Lux. Tingkat pencahayaan di lingkungan kampus A Universitas PGRI Palembang telah memenuhi standar nasional Indonesia tahun 2011 mengenai intensitas pencahayaan yang direkomendasikan sesuai dengan peruntukan ruangan.

Suhu ruangan di lingkungan kampus A Universitas PGRI Palembang telah memenuhi Peraturan Menteri Kesehatan nomor 48 tahun 2016 dengan hasil pengukuran antara $23-24^{\circ} \mathrm{C}$.

\section{DAFTAR PUSTAKA}

Bambang Yulianto, Darjati. 2017. Fisika Lingkungan. Pusat Pendidikan Sumber Daya Manusia Kesehatan Badan Pengembangan dan 
Pemberdayaan Sumber Daya Indonesia, S. N., \& Nasional, B. S. Manusia Kesehatan Kementerian Kesehatan Republik Indonesia.

Bleszeinsky, G. (2019). Partisipasi Masyarakat dalam Pelestarian Lingkungan di kawasan Pantai Padang. JESS (Journal of Education on Social Science), 3(1), 1-13.

Edi, D., \& Betshani, S., (2009). Analisis

Data dengan Menggunakan ERD dan Model Konseptual Data Warehouse. Jurnal informatika Vol 5 No 1, 71-85.

https://univpgri-palembang.ac.id diakses tanggal 29 Mei 2020

(2011). Konservasi energi pada sistem pencahayaan. SNI 036197-2000.

Peraturan Menteri Kesehatan Republik Indonesia No 48 tahun 2016 tentang Standar Keselamatan dan Kesehatan Kerja Perkantoran.

Peraturan Menteri Ketenagakerjaan Republik Indonesia Nomor 5 Tahun 2018 tentang Keselamatan dan Kesehatan Kerja Lingkungan Kerja.

Peraturan Menteri Tenaga Kerja Dan Transmigrasi Nomor 13 Tahun 